Egyptian Journal of Aquatic Biology \& Fisheries

Zoology Department, Faculty of Science,

Ain Shams University, Cairo, Egypt.

ISSN $1110-6131$

Vol. 24(6): 343 - 359 (2020)

www.ejabf.journals.ekb.eg

\title{
Age, growth and maturity of the Indian Shad, Tenualosa ilisha through otolith examination from different habitats in Bangladesh
}

Md. Borhan Uddin Ahmed ${ }^{1}$, A. K. Shakur Ahammad ${ }^{\text {* }}$, Md. Shahjahan ${ }^{2}$, Md. Fazla Rabbi ${ }^{1}$, Mohammad Ashraful Alam ${ }^{3}$, Md. Nazmus Sakib ${ }^{2}$, Md. Abul Bashar ${ }^{3}$, Md. Ataur Rahman ${ }^{4}$, Md. Yeamin Hossain ${ }^{4}$ and Yahia Mahmud ${ }^{3}$

${ }^{1}$ Department of Fisheries Biology \& Genetics, Bangladesh Agricultural University, Mymensingh2202, Bangladesh

${ }^{2}$ Department of Fisheries Management, Bangladesh Agricultural University, Mymensingh-2202, Bangladesh

${ }^{3}$ Bangladesh Fisheries Research Institute, Riverine Station, Chandpur-3602, Bangladesh

${ }^{4}$ Department of Fisheries, University of Rajshahi, Rajshahi-6205, Bangladesh

*Corresponding Author: sahammad09@yahoo.com; sahammad09@bau.edu.bd

\section{ARTICLE INFO}

Article History:

Received: July 23, 2020

Accepted: Sept. 7, 2020

Online: Sept. 13, 2020

Keywords:

Tenualosa ilisha,

Hilsa,

Otolith,

Gonad Maturity,

Length-weight relation,

Age detection,

Lunar ring

\begin{abstract}
Studies on the age, growth and maturity of Tenualosa ilisha are plagued by a lack of essential information; addressing this data gap is the aim of the present study. Six diverse habitats of hilsa across Bangladesh were chosen as sites for sample collection. For age determinations, lunar rings in the otolith of hilsa were used. The length and weight of each fish were recorded prior to otolith extraction. Extracted otoliths were polished to enable the visualization and quantification of rings. Except for the Kali River and Gaglajur Haor, age of the fish correlated strongly with both their length and weight $(r>0.95 ; p<0.05)$. Again, except for those from the Kali River and Gaglajur Haor, all of the samples exhibited positive allometric growth patterns $(b>3)$ with the fish from the Tetulia River being the most positive $(b=3.48)$. The growth of T. ilisha in the Bangladesh was described as $\mathrm{L}_{\mathrm{t}}=48.02[1-\exp \{-1.01(\mathrm{t}-0.046)\}]$ and growth performance was 3.04. The estimated $L_{m}$ for T. ilisha was as $26.04(\sim 26.00)(95 \% \mathrm{CL}=19.87$ $33.84) \mathrm{cm}$ TL based on the maximum length-based model and it was confirmed by gonad histology. These results would be effective for sustainable management of hilsa fishery in Bangladesh and neighboring countries.
\end{abstract}

\section{INTRODUCTION}

Tenualosa ilisha, the national fish of Bangladesh, is a member of the Clupeidae family and an exigent stuff of fish production in the country. It is locally called ilish, hilsa, hilsa herring, or hilsa shad. It can be found in almost every river, estuary, and marine environment in the country and has been recognizes as the largest single species of fish (Ahmed et al., 2008) and 12\% of total fish production of the country came from this Hilsa fishery (Nima et al., 2020). Hilsa adds 0.35 million metric tons (MT) annually 
(DoF, 2014) to over-all fish production of Bangladesh. According to Bala et al., (2014) hilsa embodies nearly 1\% of Bangladesh's GDP with $6-7$ million dollar earning as foreign money from trading of hilsa. It encompasses $12 \%$ of the country's entire fish production (Rahman et al., 2012). Approximately 0.45 million people get their income by harvesting hilsa and 4-5 million populaces are indirectly confer their diligence in the fishing industry through processing, transporting and marketing of this hilsa (DoF, 2015). Hilsa can grow up to $60 \mathrm{~cm}$ in length and weights of up to $4.2 \mathrm{~kg}$ (Bhaumik et al., 2012). The juvenile hilsa (up to $25 \mathrm{~cm}$ ) that return to the sea are known as "jatka" in Bangladesh. Pillay and Rosa (1963) studied the ecology of hilsa and found that they are innate to the intertidal zone, estuaries, briny water lakes, and freshwater rivers of the western portion of the Indo-Pacific zone. Its marine dispersal extends from the Persian Gulf near Iran and Iraq to the Arabian Sea and the Bay of Bengal on India's west coast. It has also been reported to occupy the seaside waters of Sri Lanka and Cochin, China (Laos). Presently, the upstream inhabitants has been severely depleted and the fish are largely concentrated in the downstream tributaries, estuaries, seaside areas, and Bay of Bengal (Haldar and Rahman, 1998; Sabbir et al., 2020). There are several factors involved in the decline of the hilsa fish in Bangladesh together with the indiscriminate and unselective exploitation of the juvenile (Jatka) hilsa for human consumption, reduced influx of water due to the Farakka barrage, increased river water contamination and silt deposition, obliteration of their migration routes, spawning, feeding, and nursing grounds by human intervention (Hasan $\boldsymbol{e t}$ al., 2020). Henceforth, there is growing apprehension among the marine biologists regarding the protection and sustainable maintenance of hilsa, which may soon require imposing different managing strategies, guidelines, and interventions.

When assessing the stock of any fish, different population parameters (e.g. growth rate, age, sex etc.) need be taken into attention. Information on age and growth is exceptionally important to almost all aspect of fisheries (Jobling, 2002). However, recently a menacing matter has been observed in hilsa of Bangladesh. The matter is the presence of matured egg in small-sized hilsa. It remains unknown whether these small size hilsa are adult or environmental factors (e.g. climate, hydrological, and ecological changes) have forced the fishes to develop premature gonad in the juvenile stage (Almukhtar et al., 2016). Also, sexual maturity can be achieve at different sizes and ages for spawning migration because the fish uptakes a lot of nourishment in the period of their migratory journey (Mohamed and Qasim, 2014; Zhang et al., 2009). A possible reasons for early gonadal development observed in hilsa may also involve genetic factors rising from inbreeding depression, tightly populated areas, food competition, and sketchy migration. It may also possible that some small-sized hilsa may persist in the river rather than return to sea and thus, reach sexual maturity in fresh water. However, this are some hypothetical saying which needs investigation for prove. On the other hand, determining the age of these fish is essential for testing this hypothesis and therefore, it is the focus of the present study.

For age determination, researchers have used diverse approaches that rely on the inquiry of the scales, fin, spines etc. However, these are all exterior structures that may be loosen and regenerated anew over the progression of fish's lifespan, especially for highly migratory fish like hilsa. Therefore, this type of external structures do not reliably illustrate the real age data for fish (Hoxmeier, 2001). In contrast, an internal structure 
like otolith is an organ that never separates from the body of fish. Otoliths are paired calcified structures used for balance and/or hearing in teleost fish (Campana, 1999). The otolith has long been known as a timekeeper in fish (Ahmed et al., 2008). This distinctive characteristic renders the otolith ring predominantly well-suited for lifecycle studies and was therefore selected for the present study.

Otoliths are naturally-occurring data loggers that use microstructures to record different chronological events related to the growth and environment experienced by the fish (Kalish, 1989). Moreover, the otolith codes critical evidence on fish's age, growth rate, form of movement, and habitat interactions that can be concluded to the population level in terms of the ecology, demography, and life-history of the species (Campana, 1999). No other biological structures is comparable to the otolith in terms of the capability to relay evidence on the age and growth array of fish (Begg $\boldsymbol{e t}$ al., 2004). However, otolith in T. ilisha does not holds annual rings known as annuli that makes using this structure for age calculation more challenging. But, lunar rings are clearly present in otolith of the hilsa which accurately and authentically reflect fish age (Rahman and Cowx, 2006). Therefore, lunar rings were used to estimate the age hilsa in the present study. Also, gonadal maturation of any fish is correlated with its age. Therefore, the aim of the present study was to establish a relationship of the gonadal maturation with the age of the fish and to determine the size at first sexual maturity. This approach in case of hilsa in Bangladesh has not yet been described in the literature and, therefore, the present study gives novel insight into the connection between the age and size of Bangladesh's utmost vital species of fish.

\section{MATERIALS AND METHODS}

\section{Sample collection and otolith extraction}

Fresh and live hilsa fish were collected arbitrarily from six discrete habitats of Bangladesh, viz Meghna River Estuary (Chandpur); Bay of Bengal (Cox's Bazar); Kali River (Kishoreganj); Tetulia River (Barisal), Padma River (Mawa, Munshiganj); and Gaglajur Haor (Mohanganj, Netrokona). Live hilsa were collected using fishing boat with the help of local fishers from each of the six habitats. Immediately after capture, fish were put into ice box filled with fine crashed ice and taken into laboratory. Geographical coordinates and water level of the sampling site is given in Table 1. A total of 30 individuals (small, medium and large, 10 fish each) were collected from each sampling site. After collection of fish, natural death occurred within 15-20 minutes. Prior to dissection, the total length (TL) and weight (BW) of each fish were recorded in $\mathrm{cm}$ and $\mathrm{g}$, respectively. Then dissection was done in the laboratory to performed otolith extraction. Then collected otoliths were washed with distilled water, air-dried, and preserved in a 1 $\mathrm{ml}$ Eppendorf tube filled one third by $100 \%$ ethanol at normal temperature.

Table 1: Longitude and latitude of sampling site

\begin{tabular}{cccc}
\hline Sampling area & Latitude & Longitude & Water body \\
\hline Chandpur & 23.23498 & 90.63631 & Lower stretches of Meghna \\
Barisal & 22.74864 & 90.4198 & Tetulia river \\
Kishoregonj & 24.14184 & 90.9331 & Kali river \\
Cox's Bazar & 21.45183 & 91.96832 & Bay of Bengal \\
Munshiganj & 23.47206 & 90.25976 & Upper stretches of Padma \\
Netrokona & 24.81687 & 91.12115 & Gaglajur haor \\
\hline
\end{tabular}




\section{Length-frequency distributions (LFDs)}

The LFDs for T. ilisha were constructed using $1.0 \mathrm{~cm}$ intervals of TL. The normal frequency distribution was fixed to the TL frequency distribution of $T$. ilisha using a computer program Microsoft Excel-add-in-solver based on Hasselblad's maximumlikelihood method described by Hasselblad (1996).

\section{Otolith processing and observation}

To visualize age mark (ring) in the otolith, combination of the acid contact method (Sinha and Jones, 1967) and the wet-dry sandpaper method (Rahman and Cowx, 2006) were used. In case of acid contact method, first of all, the otoliths were submerged into distilled water and kept one minute. The exterior part, which was convex, were rub by hand against a carborundum stone. The surface of the stone was coated by dilute hydrochloric acid. Use of acid was kept limited to not allow the edge of the otolith to contact the acid. During this procedure, the otolith was periodically inspected under a microscope to visualize growth rings. Once the rings became noticeably visible, the otolith was yet again submerged into distilled water and kept 1 to 2 minutes to eliminate the acid from the otolith surface, followed by $70 \%$ ethanol, and then absolute ethanol for the following 1 to 2 minutes. On the other hand, in wet-dry sandpaper method, a pieces of sandpaper, grit sizes ranging from 600 to 1000 were used. A circular motion with the sandpaper were used to confirm polishing of every side of the otolith evenly. This process was performed until the rings became noticeable under a microscope. Then otolith was washed in distilled water and air dried. Growth ring counting were done under a light microscope at 100x magnification with immersion oil on the slide. Approximately two out of every three otoliths were sufficiently polished and quantified for age calculation.

\section{Age calculation}

Lunar rings, which is known as daily rings, were noticeable under 100x magnifications. According to Rahman and Cowx (2006) lunar rings comprise of 11 serially-deposited, comparatively light, narrow rings, followed by 3 deeper and wider rings. These three rings are possibly formed during the spring tide (Rahman, 2001). The three deeper, wider rings together looks as if they are one thick, dark band, denoted to as a lunar ring, and are indicative of a 14 days of increment. The 14-day periodical arrival of the lunar rings happens in harmony with the lunar cycle. The accuracy and authenticity of using these sequential markings of otolith to calculate the age of a fish were proved by calculating the rings in fish raised up in captivity for known periods of time (Hayashi et al., 2001) and also by marginal increment analysis (Gartner, 1991). In the present study, the 11 daily rings were not clearly visible in few of the otoliths. Therefore, only the lunar rings (3 deeper and wider rings), which represents 14 days of increment, were counted in age calculation of the present study using the following equation.

$\mathrm{AD}=(\mathrm{LR} \times 14) \ldots \ldots \ldots \ldots \ldots \ldots \ldots \ldots(1)$

Where, $\mathrm{AD}=$ age of hilsa in days and $\mathrm{LR}=$ total number of lunar rings visible in otolith surface. 


\section{Growth Curve and Parameters}

The von Bertalanffy growth equation (VBGE) was used to describe the growth of T. ilisha and was fitted to the observed individual lengths- at- age instead of the mean length- at- age frequently used. The growth parameters of $T$. ilisha was estimated by fitting the von Bertalanffy equation (Von Bertalanffy, 1938) to the TLs at ages estimated from Otolith reading at the various sampling dates and sizes using a computer analysis (Microsoft Excel-add-in-Solver) based on Hasselblad's maximum likelihood method (Hasselblad, 1996).

The equation was: von Bertalanffy equation:

$\mathrm{L}_{\mathrm{t}}=\mathrm{L}_{\alpha}\left[1-\exp \left\{-\mathrm{k}\left(\mathrm{t}-\mathrm{t}_{0}\right)\right\}\right]$

Where, $\mathrm{L}_{\mathrm{t}}$ is the TL $(\mathrm{cm})$ at age $\mathrm{t}$ (month), $\mathrm{L}_{\alpha}$ is the asymptotic TL $(\mathrm{cm}), \mathrm{k}$ is the growth coefficient (per year), and $\mathrm{t}_{0}$ is the hypothetical age when the TL would be zero.

The growth performance index $\left(\varnothing^{\prime}\right.$ ) (Gayanilo Jr and Pauly, 1997) was calculated to provide a basis for the comparison of growth characteristics in terms of length with earlier or future studies:

$\emptyset^{\prime}=\log _{10} k+2 \log _{10} L_{\alpha}$

Where, $k$ and $L_{\alpha}$ are the VBGE parameters.

\section{Length-weight relationship}

The growth pattern was estimated through LWR with the equation: $W=a * L^{b}$, where $W$ is total body weight $(\mathrm{g})$ and $L$ is the total length $(\mathrm{cm})$. The parameters $a$ and $b$ were estimated by linear regression analyses based on natural logarithms: $\ln (\mathrm{W})=\ln (a)+b \ln (\mathrm{L})$. Extremes outliers were removed from the regression analyses according to Froese (2006). A t-test was used to verify whether $b$ values acquired in the linear regressions were significantly different from the isometric value $(b=3)$, according to the equation of Sokal and Rohlf (1987) as: $\mathrm{t}_{\mathrm{s}}=(b-3) / s_{b}$, where, $\mathrm{t}_{\mathrm{s}}$ is the t-test value, $b$ the slope, and $s_{b}$ the standard error of the slope $(b)$. Additionally, on the basis of the $b$ values of LWR (TL vs. BW), growth pattern of T. ilisha was determined.

\section{Size at first sexual maturity $\left(\mathrm{L}_{\mathrm{m}}\right)$}

Size at first sexual maturity was denoted as the size at which $50 \%$ of the individuals become sexually mature. Size at first sexual maturity $\left(L_{m}\right)$ for $T$. ilisha was estimated by the following empirical equation given by Binohlan and Froese (2009) $\log \left(L_{m}\right)=-0.1189+0.9157 * \log \left(L_{\max }\right)$, where, $L_{\max }$ is the maximum TL.

\section{Determination of gonadal maturation using histology}

In this regard, the ovary was taken out in a perforated plastic holder covering by perforated steel plates. Cleaning, infiltration and dehydration process were carried out in an automatic tissue processor. Paraffin embedded blocks were cut by microtome knife at 4-5 $\mu \mathrm{m}$ size and left the sections into a water bath at a temperature of $37^{\circ} \mathrm{C}$. The sections were placed on a glass slide and kept overnight on a slide drier hot plate at $20^{\circ} \mathrm{C}$ temperature. Then the sections were stained routinely with haematoxyline and eosin according to specific staining method described by Humason (1972). Moreover, the sample containing slide were covered by cover slip and mounted by Canada balsam. After that, photographs were taken under a compound microscope (Olympus, CX-41). 


\section{Statistical analysis}

The data obtained from the length, weight, and lunar rings of the hilsa were analyzed using SPSS v. 21 (IBM SPSS for windows, Armonk, New York, USA) and Microsoft Excel program v. 2016. Length-age and weight-age correlation were estimated from the scattered dot graph. Length and weight data were subjected to an analysis of covariance (ANCOVA) followed by a comparison of the means using Duncan's multiple range test at a 95\% confidence level to know the dependence of length and weight according to the age of the fish.

\section{RESULTS}

\section{Length-frequency distributions (LFDs)}

A total number of $180 \mathrm{~T}$. ilisha were collected from the fishers in different parts of Bangladesh during the study period (January to December 2018). Table 2 shows the descriptive statistics of maximum and minimum length and weight measurement and 95\% confidence limit (CL) of T. ilisha. The LFDs showed that the largest individual was $47.40 \mathrm{~cm}$ TL and smallest individual was $15.30 \mathrm{~cm}$ TL respectively (Fig 1) and the body weight was ranged from 36.00 to $1623.00 \mathrm{~g} \mathrm{BW}$, respectively in the Tetulia River. The 30.00-32.00 and 36.00-38.00 cm TL size group was numerically dominant (Fig 1).

Table 2: Morphometric measurements of Tenualosa ilisha in different habitat.

\begin{tabular}{lcccc}
\hline \multicolumn{1}{c}{ Sampling site } & $\begin{array}{c}\text { Min } \\
(\mathrm{TL} \mathrm{cm})\end{array}$ & $\begin{array}{c}\text { Max } \\
(\mathrm{TL} \mathrm{cm})\end{array}$ & $\begin{array}{c}\text { Length } \\
(\text { mean } \pm \text { SD })\end{array}$ & Weight $($ mean \pm SD $)$ \\
\hline Meghna River Estuary & 28.10 & 44.60 & $34.93 \pm 4.82$ & $500.17 \pm 204.26$ \\
Bay of Bengal & 28.00 & 47.40 & $36.85 \pm 5.54$ & $600.53 \pm 272.36$ \\
Tetulia River & 16.00 & 36.00 & $38.28 \pm 5.67$ & $794.87 \pm 405.55$ \\
Padma River & 28.00 & 46.00 & $34.96 \pm 4.78$ & $476.60 \pm 230.95$ \\
Kali River & 28.00 & 43.00 & $25.92 \pm 5.77$ & $211.47 \pm 131.49$ \\
Gaglajur Haor & 15.30 & 26.50 & $20.19 \pm 3.38$ & $92.73 \pm 46.53$ \\
\hline
\end{tabular}

** Abbreviations: Min, minimum; Max, maximum; SD, standard deviation; TL, total length

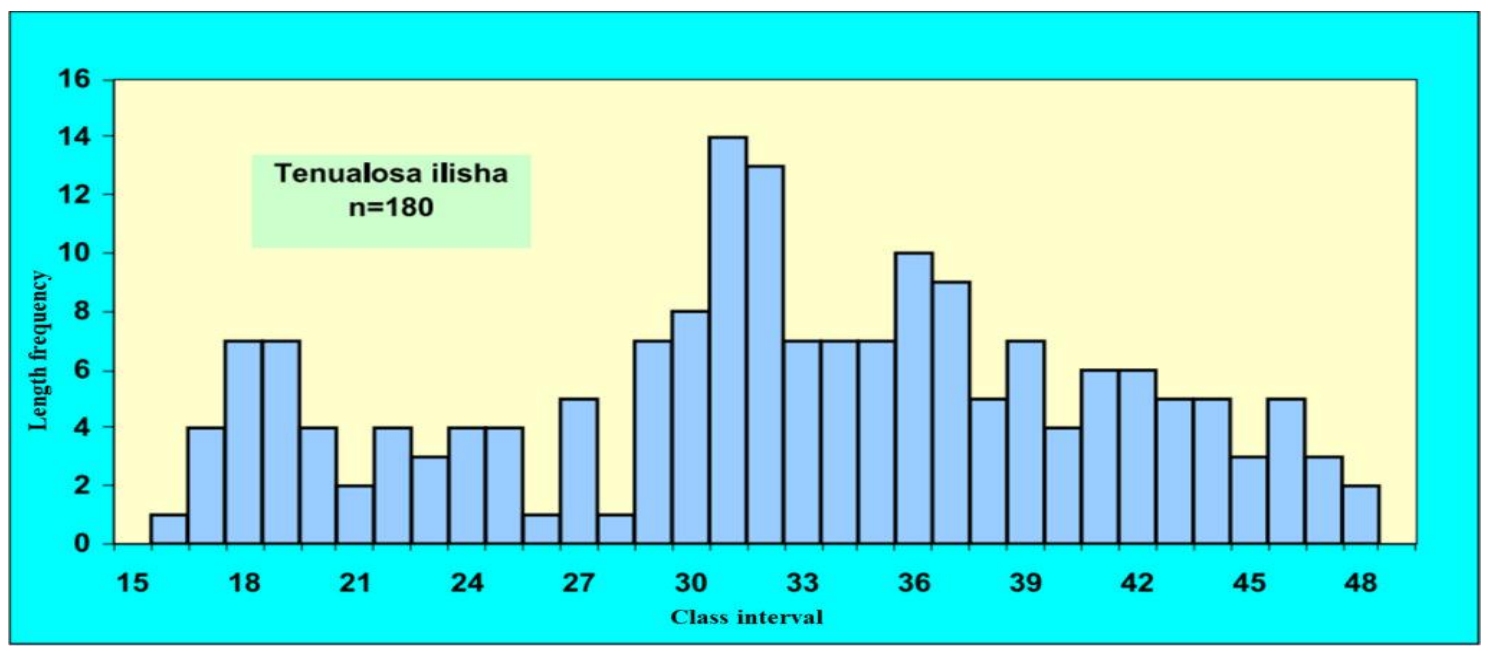

Fig. 1. Showing the length-frequency distribution of Tenualosa ilisha in different habitats of Bangladesh. 


\section{Age determination}

The age of each hilsa was estimated by counting the lunar rings shown in their otolith (Fig 2). Data acquired from these estimation indicated that the age of hilsa ranged from one to over five years old. The mean total lengths were as $24.8 \pm 5.52 \mathrm{~cm}, 32.9 \pm 4.42$ $\mathrm{cm}, 40.1 \pm 2.24 \mathrm{~cm}, 42.8 \pm 1.97 \mathrm{~cm}$, and $45.9 \pm 1.14 \mathrm{~cm}$ for the fish aged between $0-2$ years, 2-3 years, 3-4 years, 4-5, and 5-6 years, respectively (Table 3).

Table 3: The Mean length, weight, number of rings and the calculated age grouped according to size group of Tenualosa ilisha

\begin{tabular}{ccccccc}
\hline $\begin{array}{c}\text { Size } \\
\text { Group }\end{array}$ & $\begin{array}{c}\text { No. of } \\
\text { fish }(\mathrm{n})\end{array}$ & $\begin{array}{c}\text { Length } \\
(\mathrm{Mean} \pm \mathrm{SD}) \\
(\mathrm{cm})\end{array}$ & $\begin{array}{c}\text { Weight } \\
(\text { Mean } \pm \text { SD }) \\
(\mathrm{g})\end{array}$ & $\begin{array}{c}\text { Lunar ring } \\
(\text { Mean } \pm \text { SD }) \\
(\mathrm{n})\end{array}$ & $\begin{array}{c}\text { Age }(\text { Mean } \pm \text { SD) } \\
\text { Month }\end{array}$ & Year \\
\hline Small & 74 & $24.8 \pm 5.52$ & $178.3 \pm 96.20$ & $36.1 \pm 11.25$ & $16.6 \pm 5.19$ & $0-2$ \\
Medium & 60 & $32.9 \pm 4.42$ & $425.7 \pm 166.78$ & $61.9 \pm 8.38$ & $28.7 \pm 3.90$ & $2-3$ \\
Large & 24 & $40.1 \pm 2.24$ & $747.9 \pm 84.59$ & $87.1 \pm 6.39$ & $40.4 \pm 3.03$ & $3-4$ \\
Intermediate large & 14 & $42.8 \pm 1.97$ & $898.6 \pm 102.78$ & $111.5 \pm 7.80$ & $51.7 \pm 3.63$ & $4-5$ \\
Extra-large & 8 & $45.9 \pm 1.14$ & $1378.1 \pm 155.51$ & $141.6 \pm 3.96$ & $65.8 \pm 1.91$ & $5-6$ \\
\hline
\end{tabular}

** Abbreviations: $\mathrm{n}$, sample size; SD, standard deviation 

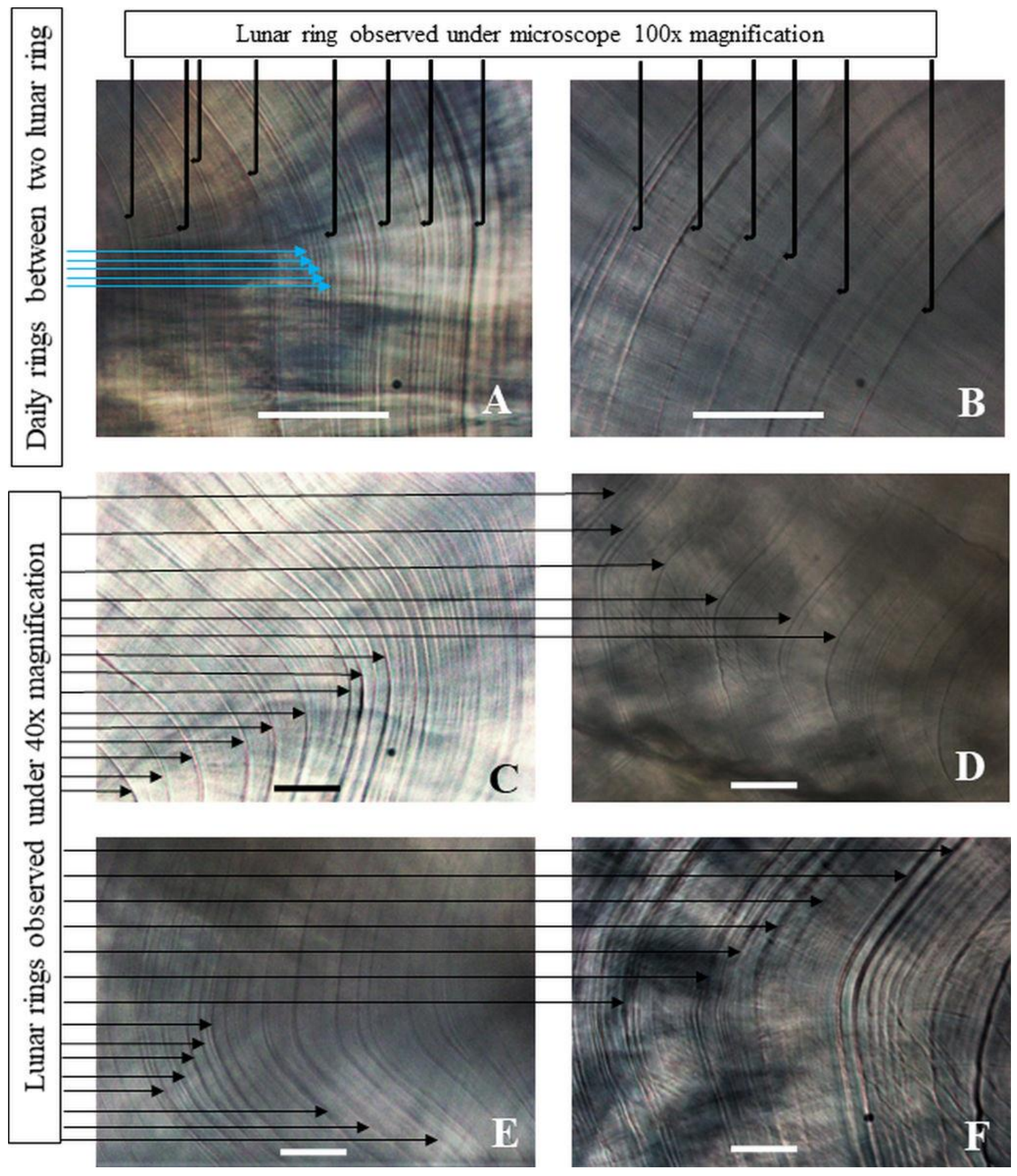

Fig. 2. Both daily and lunar rings were observed under compound microscope (CX-41, Germany). In 100x magnification (A-B); only lunar rings were also observed in 40x magnification (C-F) in sagittal otolith of Tenualosa ilisha.

\section{Growth Curve and Parameters}

The von Bertalanffy equation was the model for describing the growth for $T$. ilisha in Bangladesh and its growth curve is shown in Fig. 3. Additionally, the growth performance was estimated as 3.40. 


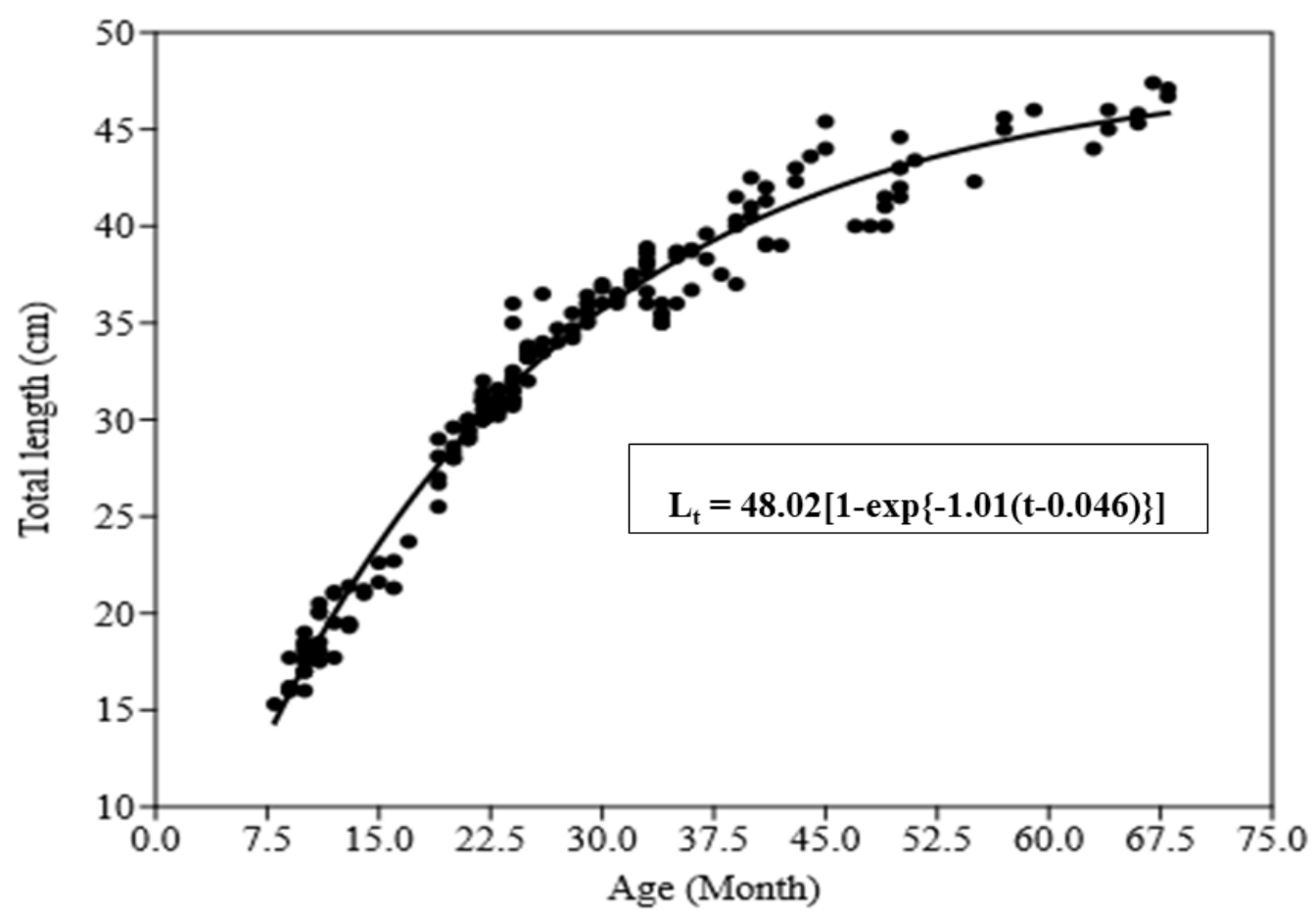

Fig. 3. Growth curve of Tenualosa ilisha in Bangladesh using von Bertalanffy model. Solid squares showing the total length of its age through otolith reading.

\section{Length-weight relationship}

The regression parameter, 95\% confidence interval of $a$ and $b$, coefficient determination $\left(r^{2}\right)$, and growth type (GT), of T. ilisha are shown in Table 4. In this study, the highest slope value $(b)$ was recorded from the Tetulia River $(b=3.51)$, followed by the Padma River $(b=3.42)$, Bay of Bengal $(b=3.32)$, Meghna River Estuary $(b=3.16)$, Kali River $(b=3.04)$, and Gaglajur Haor $(b=2.96)$ (Fig 4$)$. The results indicated positive allometric growth behavior in most of the sampling area except for those from the Kali River and Gaglajur Haor, which exhibited isometric and negative allometric growth patterns, respectively. The results obtained from the length-weight relationship analysis and their associated descriptive statistics are presented in Table 4 for all of the hilsa according to sampling site.

Table 4: The estimated parameter of Length-weight relationship parameters and associated descriptive statistics of Tenualosa ilisha in different habitats in Bangladesh

\begin{tabular}{|c|c|c|c|c|c|c|c|}
\hline Sampling area & Equation & $A$ & $b$ & CI of $a$ & CIof $b$ & $r^{2}$ & Growth type \\
\hline $\begin{array}{c}\text { Lower stretches } \\
\text { of Meghna }\end{array}$ & \multirow{6}{*}{$\mathrm{BW}=a^{*} \mathrm{TL}^{b}$} & 0.0062 & 3.16 & $0.0025-0.0155$ & $2.90-3.42$ & 0.957 & (+) Allometric \\
\hline Tetulia river & & 0.0020 & 3.51 & $0.0010-0.0042$ & $3.31-3.72$ & 0.978 & (+) Allometric \\
\hline Kali river & & 0.0094 & 3.04 & $0.0063-0.0139$ & $2.91-3.16$ & 0.989 & Isometric \\
\hline Bay of Bengal & & 0.0034 & 3.32 & 0.0011-0.0109 & $3.00-3.65$ & 0.941 & (+) Allometric \\
\hline $\begin{array}{c}\text { Upper stretches } \\
\text { of Padma }\end{array}$ & & 0.0023 & 3.42 & $0.0010-0.0052$ & $3.19-3.66$ & 0.970 & (+) Allometric \\
\hline Gaglajur haor & & 0.0115 & 2.96 & $0.0047-0.0284$ & $2.66-3.27$ & 0.936 & (-) Allometric \\
\hline
\end{tabular}

** Abbreviations: $a$, intercept; $b$, slope; CI, confidence intervals; $r^{2}$, coefficient of determination. 

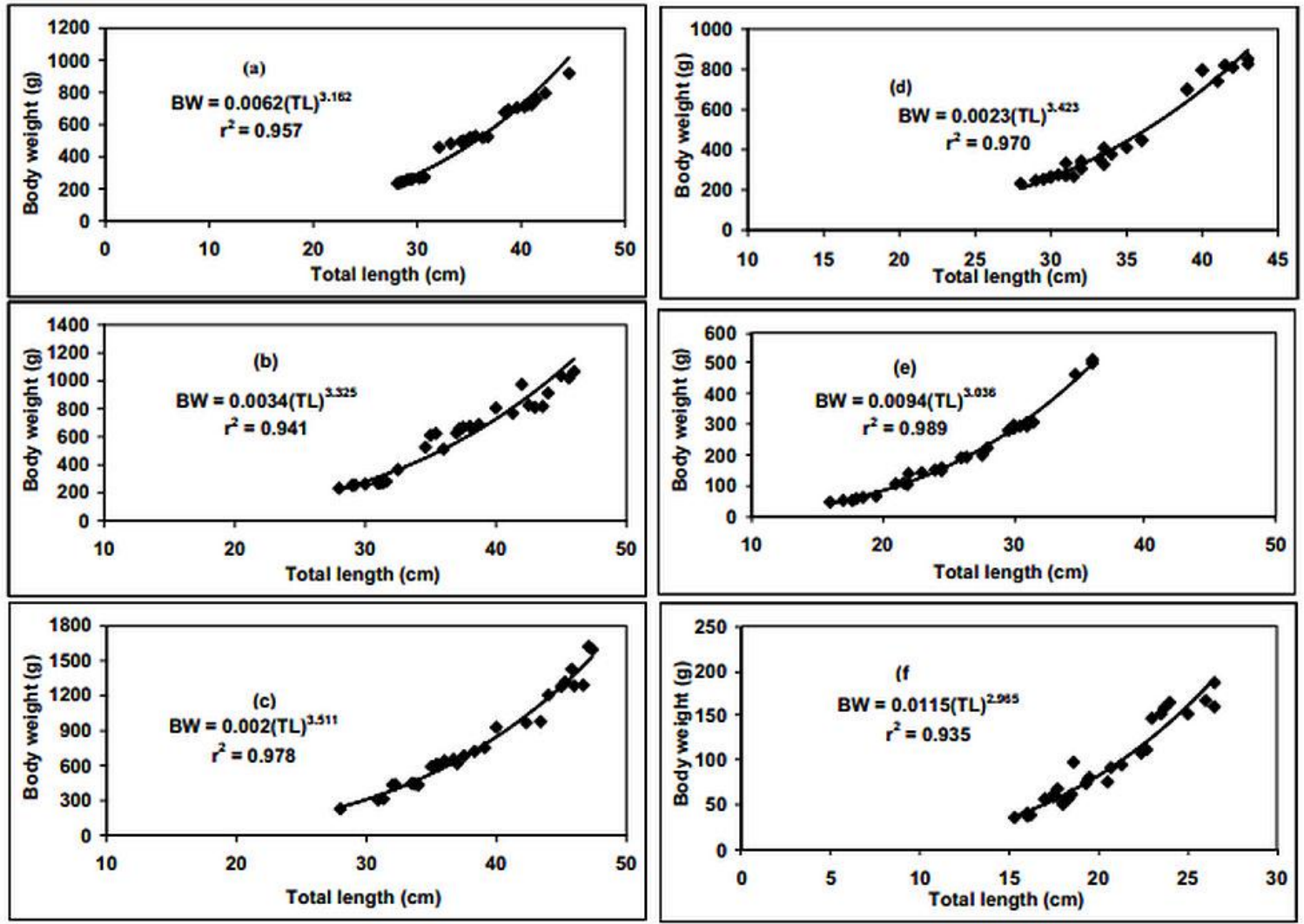

Fig. 4. Showing the relationships between total length (TL) and Body weight (BW) of Tenualosa ilisha in (a) Lower stretches of Meghna, (b) Bay of Bengal, (c) Tetulia River, (d) Upper stretches of Padma, (e) Kali river and (f) Gaglajur haor of Bangladesh

\section{Size at first sexual maturity $\left(\mathrm{L}_{\mathrm{m}}\right)$}

The estimated $L_{m}$ for T. ilisha was as $26.04(\sim 26.00)(95 \% \mathrm{CL}=19.87-33.84) \mathrm{cm}$ TL based on the Lm in the Bangladesh. Finally, it was confirmed by histological analysis of gonad. The age at first sexual maturity was as 1.2 years that was confirmed by otolith observation.

\section{Determination of gonad al maturation using histology}

Gonadal maturation of hilsa from six location were determined using some common developmental characteristics, viz: oocyte color and size, number of nucleoli, follicular layer appearance, distribution of cytoplasmic attachments etc. Samples from October were used for gonad histology as this is the peak period of sexual maturation for hilsa (Hossain et al., 2018). Depending on the stage of maturity, the macroscopic view of gonads reformed in size and colour, number of nucleoli changed. Fully developed ovary was confirmed by advanced yolk, primary growth oocytes, number of nucleoli and follicular layer by visual observation of hilsa gonad cross section, unveiled under microscope (Fig 5). In the Meghna, Tetulia, Bay-of-Bengal and Padma river sample, the maturation of ovary were found linear with the age and size of the hilsa. However, in case of Kali River, Kishoregonj and Gaglajur haor, Netrokona, small size and low aged hilsa 
were surprisingly found with matured ovary. Minimum size at sexual maturity was recorded in fish aged 11 month (TL $18.5 \mathrm{~cm}$ ) and 12 months (TL $21 \mathrm{~cm}$ ) in Gaglajur haor, Netrokona and Kali River, Kishoreganj, respectively.
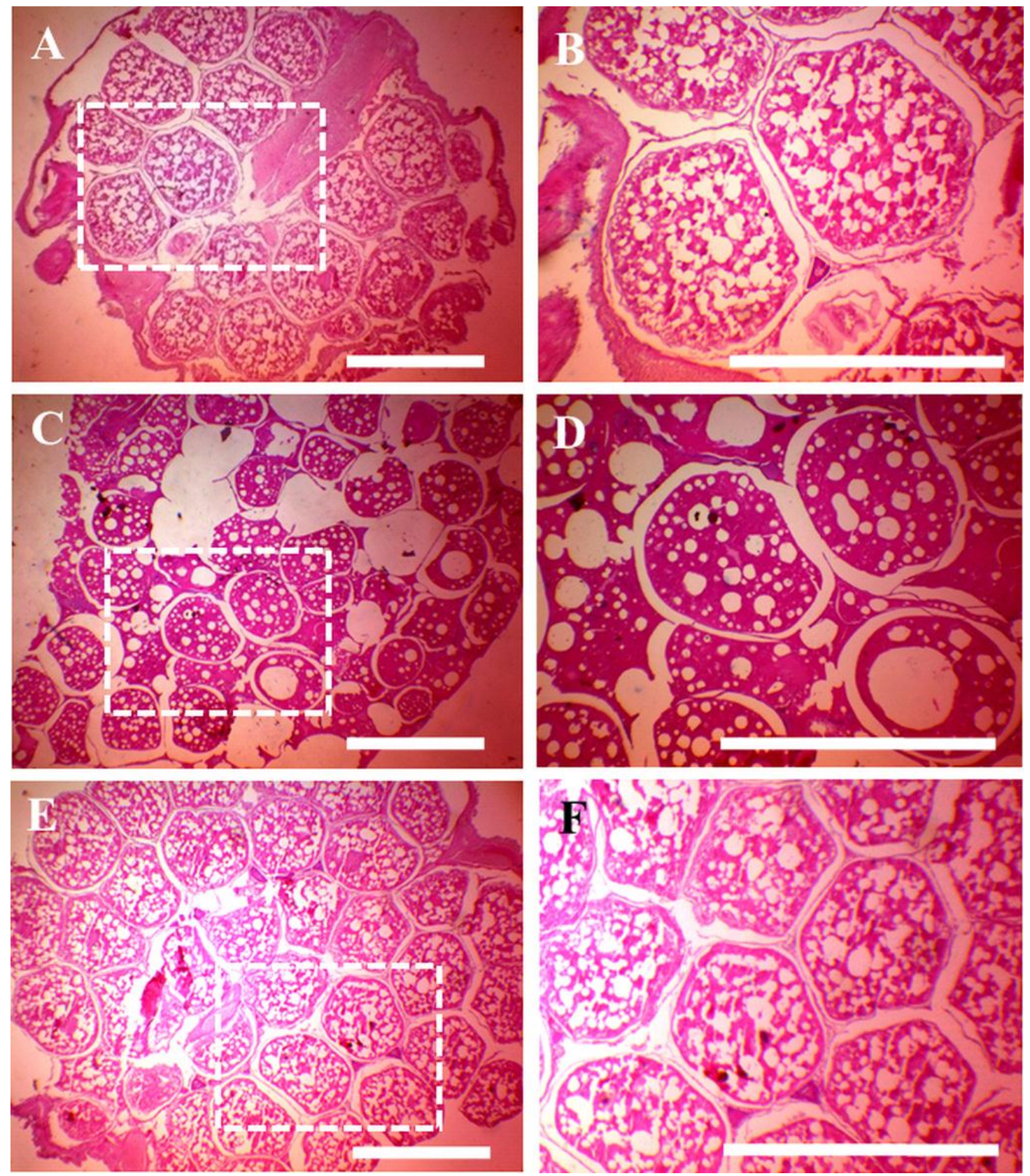

Fig. 5. Overy of hilsa from all six habitats showing mature stage of ovarian development where oocytes are in secondary vitellogenesis (A-F). A-B, Small sized $(22 \mathrm{~cm}) 10$ months old hilsa. C-D, Medium sized $(32 \mathrm{~cm}) 24$ months old hilsa. E-F, Large sized $(47 \mathrm{~cm}) 67$ months old hilsa. Right side panels showing magnified view of boxed areas of the left side panels. $(\mathrm{H} \& \mathrm{E} \times 40)$ 


\section{DISCUSSION}

Evidence on the age, growth and maturity of Tenualosa ilisha through otolith inspection is quite rare in available literature in Bangladesh as well as somewhere else. However, Few attempt have been done on several aspects of T. ilisha in Bangladesh and neighboring countries (Amin et al., 2002; Rahman and Cowx, 2006; Ahmed et al., 2008; Bala et al., 2014). In the present study, it was quite difficult to take out samples less than $15.3 \mathrm{~cm}$ and higher than $47.40 \mathrm{~cm}$ due to the legislation of fishing net selectivity in Bangladesh (Hossain et al., 2016) and the absence of hilsa in the fishing ground during study period (Ahamed et al., 2017; Hossen et al., 2019). However, the focus of the present study was to find the gonad maturation of hilsa which generally not occurs beyond this size range obtained in the present study (Rahman and Cowx, 2006). Therefore, the size range of the hilsa used in the present study has no effect on the final result.

The external anatomy of the otolith from T. ilisha determined in the present study are similar to those described by Ahmed et al., (2008) by means of its structure, color and daily ring appearance under microscope. The otolith were also comparable to other species of clupeid fish by means of its serrate, anterior and posterior part and the otolith was little convex like other clupeid fish (Methot Jr, 1983). In the present study, less than $10 \%$ unreadable area of otolith (estimated by SigmaPlot.v.13) were accepted for analysis, which is consistent with the study of Rahman and Cowx (2006) that reported similar values (10\%). On the other hand, Waldron and Gerneke (1997) and Quddus et al. (1984) considered less than the $20 \%$ unreadable area of otolith for estimation of result, indicating that less than $10 \%$ unreadable surface area of otolith in the present study is more reliable and acceptable than their study. The otoliths investigated in the present study were slightly convex or oval in shape that made polishing them challenging. When the top part was appropriately polished, the edges were not; yet, any additional polishing may cause efface of the rings from the top portion while without additional polishing, rings around the edges were invisible. Hence, the otolith from $T$. ilisha were very difficult to polish and required additional care and vigilance. Besides, The 11 daily rings described by Rahman and Cowx (2006) using 1000x magnification was tough to visualize in the present study due to less magnification (100x magnification in the present study).

Origination of annulus in fish is usually believed to coincide with the spawning period (Pannella, 1980). Furthermore, the attributes for annulus formation and its timing is related to gonadal ripening and may be partially reliant on nutrient availability, starvation, ecological variation, and stress (Hossain et al., 2018). In fish, starvation commonly occurs at exceptionally low temperatures. In Bangladeshi waters, temperature falls are not sufficiently detrimental to fully cease fish feeding. Therefore, a partial break in growth is very uncommon for hilsa, which could explain the absence of annuli in its otolith. Besides, both migration and the formation of lunar rings take place according to the lunar cycle and hilsa are highly migratory. This can explain the reason behind formation of lunar rings in its otoliths.

The age groups determined in the present study are in compliance with those reported by De and Datta (1990) who assessed the age of hilsa by length frequency analysis and found between 2-6 years in a population where $90 \%$ individual were between $25-75 \mathrm{~cm}$ in length. The length and weight at age results obtained in the present study (except for 
those collected from the Kali River and Gaglajur Haor) support the outcomes presented by Blaber $\boldsymbol{e t}$ al. (2003) for hilsa from Indian water. In addition, Hossain et al. (2018) reported a similar association of fish growth with age using otolith ring analysis from the Padma and Meghna rivers. Karim et al. (2015) also directed a study on the daily rings of hilsa otoliths and reported parallel outcomes in terms of length at age as were generated in the present study. However, the length at age values from all of the habitat in the present study was a little lower than those described by Ahmed $\boldsymbol{e t}$ al. (2008). This size variations observed between similarly-aged hilsa may be due to habitat-associated gene expression variations, climate change, food accessibility, or an amalgamation of these factors. Detecting the underlying reason of this phenomenon unequivocally need studies that include a high-resolution inspection of the genes associated to gonad growth (e.g. Dmrt, Foxl2, etc.).

To analyze the growth patterns of T. ilisha in Bangladesh, single growth model was applied without justification for the best fitting model. The estimated growth parameters were within the acceptable limits for fishes (Rahman $\boldsymbol{e t}$ al., 2012) and were consistent with the values reported for this species from other waters. Several studies reported the growth parameters based on length-frequency distributions. However, the present study observed the growth parameters from hard-part analysis (otolith readings). The estimated growth performance index ( $\left.\varnothing^{\prime}\right)$ for T. ilisha was different than earlier studies and it might be due to environmental or genetic factors, which were not accounted in this study.

In case of the length-weight relationship, a study directed by Flura et al. (2015) in the Tetulia River reported positive allometric growth patterns for both male $(b=3.02)$ and female $(b=3.08)$ hilsa and robust positive correlations between length and weight (male; $r^{2}=0.969$, female; $r^{2}=0.968$ ), which justifies the results attained in the present study (except for the Kali River and Gaglajur Haor samples). In contrast, Flura et al. (2015) observed growth patterns in fish from the Meghna Estuary of Chandpur that they characterized as isometric after analyzing the length-weight relationship; these findings disagree with the positive allometric growth found in the present study. This disparity is likely clarified by variances in the study periods and the subsequent difference in food availability (Khatun et $\boldsymbol{a l . , 2 0 1 8}$ ), the climate (Khatun $\boldsymbol{e t}$ al., 2019), and potentially, gene-environment interactions (Hossain et al., 2018).

In case of size at first sexual maturity, according to Banerji and Krishnan (1973) The Lm was $19 \mathrm{~cm}$ in TL in Mandapam which is lower than our study. In addition, AlBaz and Grove (1995) also recorded the Lm for T. ilisha as $41.5 \mathrm{~cm}$ in TL which is higher than our present findings. Size at first sexual maturity may be variable according to the environment where a fish lives (Hossen et al., 2019). It may also differ according to food, temperature, niche, ecology, somatic resources of the fish and several genetic factors (Jonsson and Jonsson, 2011). Variation in Lm in the present study can be explained with this statement as the samples used in the present study was isolated from the two study addressed above.

\section{CONCLUSION}

For stock assessment of any fish, evidence-based calculation is essential to develop suitable management and conservation tactics. Feeding, spawning, migration and other biological activities of fish are prominently affected by their age. Age records of hilsa in 
the present investigation offers a baseline for calculating their growth, mortality and productivity. Premature gonad ripening of hilsa, a menacing problem in Bangladesh is clearly unlocked in the present research, so that necessary management plan can be taken to alleviate the problem. In conclusion, the present study will support new researchers to operate additional research in this area and assist policy makers to develop more applicable strategies so that hilsa population continues its position in the economy, culture, and cuisine of Bangladesh.

\section{ACKNOWLEDGEMENTS}

The authors would like to extend their heartfelt gratitude to the Strengthening of Hilsa Research in Riverine Station Chandpur Project, Bangladesh Fisheries Research Institute (BFRI) for financial supports of this research.

\section{REFERENCES}

Ahamed, F.; Ahmed, Z.F.; Hossain, M.Y.; and Ohtomi, J. (2017). Growth and longevity of the mola carplet Amblypharyngodon mola (Cyprinidae) in the Payra River, southern Bangladesh. Egypt. J. Aquat. Res., 43(4): 291-295.

Ahmed, M.S.; Sharif, A.S.M and Latifa, G.A. (2008). Age, Growth and Mortality of Hilsa Shad, Tenualosa ilisha in the River Meghna, Bangladesh. Asian J. Biol. Sci., 2008; 1:69-76.

Ahmed, M.S.; Sharif, A.S.M. and Latifa, G.A. (2008). Age, Growth and Mortality of Hilsa Shad, Tenualosa ilisha in the River Meghna, Bangladesh. Asian J. Biol. Sci., 1:69-76.

Al-Baz, A.F. and Grove, D.J. (1995). Population biology of sbour Tenualosa ilisha (Hamilton-Buchanan) in Kuwait. Asian Fish. Sci. , 8(3-4): 239-254

Almukhtar, M.A.; Jasim, W. and Mutlak, F. (2016). Reproductive Biology of Hilsa Shad Tenualosa ilisha (Teleostei: Clupeidae) During Spawning Migration in the Shatt Al Arab River and Southern Al Hammar Marsh, Basra, Iraq. J. Fish. Aquat. Sci., 11:43.

Amin, S.M.N.; Rahman, M.A.; Haldar, G.C.; Mazid, M.A. and Milton, D. (2002). Population dynamics and stock assessment of hilsa shad, Tenualosa ilisha in Bangladesh. Asian Fish. Sci. , 15: 123-128.

Bala, B.K.; Arshad, F.M.; Alias, E.F.; Sidique, S.F.; Noh, K.M.; Rowshon, M.K. and Islam, M.M. Islam. (2014). Sustainable exploitation of hilsa fish (Tenualosa ilisha) population in Bangladesh: Modeling and policy implications. Ecol., 283:19-30.

Banerji, S.K. and Krishnan, T.S. (1973). Acceleration of assessment of fish populations and comparative studies of similar taxonomic groups. In Proceedings of the Symposium on Living Resources of the Seas Around India. CMFRI Special Publication, Cochin, India, p.158-175.

Begg, G.A.; Campana, S.E. and Fowler, A.J. (Eds.). (2004). Fish Otolith Research and Applications: Proceedings of the Third International Symposium on Fish Otolith Research and Application, Townsville, Queensland, Australia, 11-16 July 2004. CSIRO. 
Bhaumik, U.; Mukhopadhyay, M.K.; Shrivastava; Mukhopadhyay N.P.; Sharma, Shrivastava A.P. and Sharma A.P. (2012). The largest recorded Hilsa (Tenualosa ilisha) in India from Tapti estuary, Gujarat. Fish. Chimes,. 31:57-58.

Binohlan, C. and Froese, R. (2009). Empirical equations for estimating maximum length from length at first maturity. J. Appl. Ichthyol., 25: 611-3.

Blaber, S.J.M.; Milton, D.A.; Chenery, S.R. and Fry, G. (2003). New insights into the life history of Tenualosa ilisha and fishery implications. Am. Fish. Soc. Symp., 35: 223-240.

Campana, S.E. (1999). Chemistry and composition of fish otoliths: pathways, mechanisms and applications. Mar. Ecol. Prog. Ser., 188: 263-297.

Campana, S.E. and Thorrold, S.R. (2001). Otoliths, increments, and elements: keys to a comprehensive understanding of fish populations? Can. J. Fish. Aquat. Sci., 58: 30-38.

Campana, S.E.; Secor, D.H. and Dean, J.M. (1995). Recent developments in fish otolith research. University of South Carolina Press., pp. 89-99.

De, D.K., and Datta, N. (1990). Age, growth, length-weight relationship and relative condition in hilsa, Tenualosa ilisha (Fisher and Bianchi, 1984) from the Hooghly estuarine system. Indian. J. Fish., 37: 199-200.

DoF (Department of Fisheries). (2014). National fish week, compendium (In Bengali). Department of Fisheries, Ministry of Fisheries and Livestock, Dhaka, Bangladesh.

DoF (Department of Fisheries). (2015). National fish week, compendium (In Bengali). Department of Fisheries, Ministry of Fisheries and Livestock, Dhaka, Bangladesh.

Flura, M.Z.; Rahman, B.S.; Rahman, M.A.; Alam, M.A. and Pramanik, M.H. (2015). Length-weight relationship and GSI of hilsa, Tenualosa ilisha (Fisher and Bianchi, 1984) fishes in Meghna River, Bangladesh. Int. J. Nat. Soc. Sci., 2: 8288

Froese, R. (2006). Cube law, condition factor and weight-length relationships: history, meta- analysis and recommendations. J. Appl. Ichthyol., 22:241-253.

Gartner, J.V. (1991). Life histories of three species of lantern fishes (Pisces: Myctophidae) from the eastern Gulf of Mexico. Mar. Biol. , 111: 11-20.

Gayanilo Jr, F.C. and Pauly, D. (1997). The FAO-ICLARM Stock Assessment Tools (FiSAT) Reference Manual. 262P. FAO Computerized Information Services. Fisheries, (8).

Grant, A. (Ed.) (1992). Age determination and growth in fish and other aquatic animals. Aus. J. Mar. Freshwater. Res., 43: 879-1330.

Haldar, G.C. and Rahman, M.A. (1998). Ecology of hilsa, Tenualosa ilisha (Fisher and Bianchi, 1984)). 1998. In Proceedings of BFRI/ACIAR/CSIRO Workshop on Hilsa Fisheries Research in Bangladesh, held on 3-4 March, 1998 at Bangladesh Agricultural Research Council, Dhaka, Bangladesh, pp. 3-4.

Hasan, M.R.; Mawa, Z.; Ul-Hassan, H.; Rahman, M.A.; Tanjin, S.; Ahmed Abro, N.; Gabol, K.; Bashar, M.A.; Jasmine, S.; Ohtomi, J. and Hossain, M.Y. (2020). Impact of eco-hydrological factors on growth of the Asian stinging catfish Heteropneustus fosslis (Bloch, 1794) in a Wetland Ecosystem. Egyptian Journal of Aquatic Biology and Fisheries, 24(5): 77-94.

Hasselblad, V. (1996). Estimation of parameters for a mixture of normal distributions. Technometrics., 8(3): 431-444. 
Hayashi, A.; Kawaguchi, K.; Watanabe, H. and Ishida, M. (2001). Daily growth increment formation and its lunar periodicity in otoliths of the myctophid fish Myctophum asperum (Pisces: Myctophidae). Fisheries. Science,. 67: 811-817.

Hossain, M.A.R.; Das, I.; Genevier, L.; Hazra, S.; Rahman, M. and Barange, M. (2018). Biology and fisheries of Hilsa shad in Bay of Bengal. Sci. Total Environ., 651: 1720-1734.

Hossain, M.Y.; Pramanik, M.; Uddin, M.P.N.; Hossen, M.A.; Nawer, F.; Khatun, D.; Rahman, O.; Ahmed, Z.F. and Ahamed, F. (2018). Life-history traits of Pool barb Puntius sophore (Cyprinidae) in different Ecosystems of Bangladesh. Indian. J. Mar. Sci., 47(7): 1446-1457.

Hossain, M.Y.; Hossen, M.A.; Islam, M.M.; Pramanik, M.N.U; Nawer, F.; Paul, A.K.; Hameed, H.A.; Rahman, M.M.; Kaushik, G. and Bardoloi, S. (2016). Biometric indices and size at first sexual maturity of eight alien fish species from Bangladesh. Egypt. J. Aquat. Res., 42(3): 331-339

Hossen, M.A.; Rahman, M.A.; Hossain, M.Y.; Islam, M.A.; Hasan, M.R.; Mawa, Z. and Ohtomi, J. (2019). Estimation of relative growth of Minor carp Labeo bata (Cyprinidae) through multi- linear dimensions. Lakes. Reserv. Res. Manag., 24(3): 302-307.

Hossen, M.A.; Hossain, M.Y.; Pramanik, M. N.U.; Rahman, M.A.; Islam, M.A. and Nawer, F. (2019). Biometry, sexual maturity, natural mortality and fecundity of endangered halfbeak Dermogenys pusilla (Zenarchopteridae) from the Ganges River in northwestern Bangladesh. Indian. J. Mar. Sci., Vol. 48 (10): 1548-1555

Hoxmeier, R.J.H.; Aday, D.D.; and Wahl, D.H. (2001). Factors influencing precision of age estimation from scales and otoliths of bluegills in Illinois reservoirs. N. Am. J. Fish. Manag. 21: 374-380.

Humason, G.L. (1972). Specific staining methods. Animal tissue techniques. WH Freeman and Co., San Francisco, CA, 183-5.

Jobling, M. (2002). Environmental factors and rates of development and growth. 2002. Handbook of Fish Biology and Fisheries, 1:97-122.

Jonsson, B. and Jonsson, N. (2001). Habitats as Template for Life Histories. In Ecology of Atlantic Salmon and Brown Trout. Springer, Dordrecht, pp. 1-21.1.

Kalish, J.M. (1989). Otolith microchemistry: validation of the effects of physiology, age and environment on otolith composition. J. Exp. Mar. Biol. , 132: 151-178.

Karim, R.; Roy, K.C.; Roy, P.R. and Ahmed, Z.F. (2015). Age and growth of hilsa shad, Tenualosa ilisha (Hamilton, 1822) of the river Tentulia in Bangladesh. J. Fish., 3: 227-232.

Khatun, D.; Hossain, M.Y.; Nawer, F.; Mostafa, A.A. and Al-Askar, A.A. (2019). Reproduction of Eutropiichthys vacha (Schilbeidae) in the Ganges River (NW Bangladesh) with special reference to potential influence of climate variability. Environ. Sci. Pollut. Res., 26(11): 10800-10815.

Khatun, D.; Hossain, M.Y.; Parvin, M.F. and Ohtomi, J. (2018). Temporal variation of sex ratio, growth pattern and physiological status of Eutropiichthys vacha (Schilbeidae) in the Ganges River, NW Bangladesh. J. Zool \& Ecol., 28(4): 343354. 
Methot Jr, R.D. (1983). Seasonal variation in survival of larval northern anchovy, Engraulis mordax, estimated from the age distribution of juveniles. Fishery Bulletin. U.S.A, 81: 741-750.

Mohamed, A.R.M. and Qasim, A.M. (2014). Stock assessment and management of hilsa shad (Tenualosa ilisha) in Iraqi marine waters, northwest Arabian Gulf. Int. J. Fish. Aquat. Stud. , 1:1-7.

Nima, A.; Hossain, M.Y.; Rahman, M.A.; Mawa, Z.; Hasan, M.R.; Islam, M.A.; Tanjin, S.; Sabbir, W.; Bashar, M.A. and Mahmud, Y. (2020). Temporal variations of length, weight, and condition of Hilsa shad, Tenualosa ilisha (Hamilton, 1822) in the Meghna River, Southeastern Bangladesh. Egyptian Journal of Aquatic Biology and Fisheries, 24(2): 481-494.

Panfili, J.; De Pontual, H.; Troadec, H. and Wrigh, P.J. (2002). Manual of fish sclerochronology. (IFREMER-IRD) $1^{\text {st }} \mathrm{Ed}^{\mathrm{n}}$., Brest, France.

Pannella, G. (1980). Growth patterns in fish sagittae. In, Skeletal growth of aquatic organirms: biological records of environmental changes, edited by D.C. Rhoads and R. A. Lutz, Plenum Press, New York, p. 519-560.

Pillay, S.R. and Rosa, H. Jr. (1963). Synopsis of biological data on hilsa, Hilsa ilisha (Hamilton, 1882). FAO Fisheries Biology Synopsis, 25:1-6.

Quddus, M.M.A.; Shimizu, M. and Nose, Y. (1984). Comparison of age and growth of two type of Hilsa ilisha in Bangladesh waters. Bull. Japan. Soc. Sci. Fish., 50: $51-57$.

Rahman, M.A.; Alam, M.A.; Hasan Hasan, S.J. and Jaher, M. (2012). Hilsa fishery management in Bangladesh. Hilsa: Status of fishery and potential for aquaculture, pp 40-60.

Rahman, M.J. (2001). Population biology and management of hilsa shad (Tenualosa ilisha) in Bangladesh (Doctoral Dissertation) University of Hull, England, pp. 253.

Rahman, M.J. and Cowx, I.G. (2006). Lunar periodicity in growth increment formation in otoliths of hilsa shad (Tenualosa ilisha, Clupeidae) in Bangladesh waters. Fish. Res.., 81: 342-344.

Sabbir, W.; Hossain, M.Y.; Rahman, M.A.; Hasan, M.R.; Mawa, Z.; Tanjin, S.; UlHassan, H. and Ohtomi, J., (2020). First Report on Condition Factor of Panna heterolepis (Trewavas, 1977) in the Bay of Bengal (Southwestern Bangladesh) in Relation to Eco-Climatic Factors. Egyptian Journal of Aquatic Biology and Fisheries, 24(2): 591-608.

Sinha, V.R.P. and Jones, J.W. (1967). On the age and growth of the freshwater eel (Anguilla anguilla). J. Zool. Journal of Zoology, 153: 99-117.

Sokal, R.R.; Rohlf, F.J. (1987). Introduction to biostatistics. New York.

von Bertalanffy, L. (1938). A quantitative theory of organic growth (inquiries on growth laws. II). Hum. Biol., 10(2): 181-213.

Waldron, M.E. and Gerneke, D.A. (1997). Comparison of two scanning electron microscope techniques for examining daily growth increments on fish otoliths. J. Fish Biol., 50: 450-454.

Zhang, J.; Takita, T., and Zhang, C. (2009). Reproductive biology of Ilisha elongata (Teleostei: Pristigasteridae) in Ariake Sound, Japan: Implications for estuarine fish conservation in Asia. Estuar. Coast. Shelf Sci., 81:105-113. 